\title{
Wierzący, ale niepraktykujący. Neutralność ideologiczna jako alibi naukowości postpolitycznej politologii
}

\section{Faithful but Not Practicing: Ideological Neutrality as an Alibi for Science in the Era of Post-Political Politology}

\begin{abstract}
This article illustrates the presumed axiological and ideological neutrality of modern Polish politology. Theoretical cognition in social sciences is set in an ideological perspective of various social classes. Political science, similarly to other fields in the realm of social sciences, remains under the strict influence of the variables of awareness, strongly situated in European culture based on individualism. In terms of meaning, content and understanding, social sciences are autonomous to a significantly lesser extent. Political science seems to legitimize the current institutional order, which petrifies the power of multinational corporations over seemingly independent states, labor, the natural world and the individual, as well as the collective mind. This is precisely the reason, why a critical, non-partisan and autonomous scientist must be guided by a globally understood sense of rationality in his/her analysis of social problems and developmental tendencies proposed by the neoliberal configuration of "capitalism without borders".
\end{abstract}

Keywords: ideology, theoretical cognition, conflict of redistribution, the ideological function of political science, critical politology, social and planetary rationality

\section{Między ideologią a nauką}

Kryzys stagnacji gospodarki kapitalistycznej oraz niemożność jego przezwyciężenia przy użyciu instrumentarium liberalizmu gospodarczego każe się zastanowić, co dalej. Dlatego nie ustaje debata ideologiczna między liberałami ekonomicznymi (i ich skrajniejszą odmianą - neoliberałami, libertarianami), liberałami socjalnymi, socjaldemokratami i socjalistami. Dwa tematy dominują. Pierwszy dotyczy efektywności i barier rozwojowych poszczególnych 
wariantów kapitalizmu, drugi - nowej roli państwa i jego dalszej demokratyzacji. Jak pisze Geoffrey Ingham, „te różnorodne punkty widzenia odzwierciedlają istnienie stałej walki politycznej o skalę i zakres roli państwa w społeczeństwie kapitalistycznym" (Ingham, 2011, s. 229). Walka ta toczy się także w subtelniejszym języku debaty naukowej. Nauki społeczne wraz z filozofią są bowiem duchowym echem praktyki społecznej. Ten fakt tłumaczy specyfikę nauk społeczno-humanistycznych w porównaniu ze zmatematyzowanym przyrodoznawstwem i naukami stosowanymi. Są poważne argumenty na przekonanie, że nauki społeczne głównego nurtu stanowią tylko ideologiczną formę świadomości społecznej - ich główną funkcją publiczną jest naturalizacja ładu społecznego, a ten nie dla wszystkich jest równie łaskawy. Oczywiście jeżeli prawdziwa jest konstruktywistyczna teza o społecznym tworzeniu rzeczywistości. „Jeśli bowiem rzeczywistość kultury jest w swoich zasadniczych rysach wytworem społecznym, a zasadniczym mechanizmem jej budowy jest rozpowszechnianie przekonań, to decydującą kwestią dla kształtu społecznych faktów jest skuteczne oddziaływanie na opinie innych, to znaczy skuteczne narzucanie definicji sytuacji” (Soin, 2017, s. 32). Sprzyja tej tendencji, ogromnie teraz ceniony, pluralizm podejść badawczych. Zapewnia on wewnętrzną dynamikę debacie naukowej w złożonej wspólnocie badaczy. Wydawałoby się więc, że dzięki pluralizmowi paradygmatów rosną szanse poznawcze. Ale są to najczęściej paradygmaty niespójne, niewspółmierne, a nawet sprzeczne z sobą (np. psychodynamiczny i humanistyczny paradygmat w psychologii, ekonomia neoklasyczna i ekonomia instytucjonalna). Politolog staje do boju na dwóch frontach: $\mathrm{z}$ jednej strony ma być otwarty na konfrontacje $\mathrm{z}$ innymi paradygmatami niż własny, z drugiej jednak powinien konfrontować własny paradygmat z pozamyślową rzeczywistością (Krauz-Mozer, Ścigaj, 2013, s. 17-19; Blok, 2013). A zatem problem realizmu poznawczego jest wciąż aktualny mimo postmodernizacji (radykalnej subiektywizacji) humanistyki, ontologicznego inflacjonizmu i relatywizmu pojęciowego głoszonego przez współczesnych filozofów poznania (Jacques Derrida, Richard Rorty, Ludwig Wittgenstein). Inaczej nauka by się nie różniła od luźnych spekulacji i swobodnego bredzenia, tworzyłaby tylko „postmodernistyczną kulturę pozoru” (Soin, 2017).

Według stanowiska postmodernistów kontekstualność i sytuacyjność aktów poznawczych pociąga za sobą kontekstualność zarówno podmiotów poznania, jak i jego przedmiotów. Badacz jest tutaj uczestnikiem praktyki poznawczej. Jako podmiot konkretny mówi w danym języku dyscypliny, posługuje się określonym rodzajem racjonalności przekonań, poznaje rzeczywistość $\mathrm{w}$ ramach jakiegoś projektu obiektywizującego, często z funduszy publicznych. Dlatego również przedmiot poznania jest tylko korelatem aktywności poznawczej politologa, ukierunkowanej na rozumienie $w$ ramach wyspecjalizowanej prak- 
tyki poznawczej. Ta zaś zawsze stanowi jedynie ogniwo ludzkich zmagań z materią przyrody i z uzależnieniem własnej egzystencji od konkretnej, historycznej wspólnoty życia i pracy. Sytuacja poznawcza ma zatem wiele aspektów: nie tylko epistemiczny i językowy, ale także społeczny, psychologiczny, ideologiczny czy historyczny (Tuchańska, 2012, s. 220-223). Jednak „[...] bez idei prawdy nie jest możliwy ani język, ani myśl. Chociaż z jednej strony zgodność $\mathrm{z}$ faktami jest warunkiem prawdziwości zdania, to $\mathrm{z}$ drugiej strony właśnie $\mathrm{w}$ prawdziwych wypowiedziach ustala się (opisowe) znaczenie słów" (Soin, 2017, s. 91).

Przyjmujemy tutaj Althusserowską charakterystykę ideologii jako systemu przedstawień, którego funkcja praktyczna przeważa nad funkcją poznawczą (teoretyczną) (Althusser, 2009, s. 267). Te przedstawienia to rozpowszechnione, zinternalizowane przekonania (kategorie pojęciowe, wartości, ideały, mity, praktyczne recepty) utrwalone w moralności, religii, filozofii, prawie, w doktrynach politycznych, w popkulturze, w myśleniu potocznym. Sterują one, jako konwencjonalne mądrości, działaniami ludzi w gospodarce, w polityce, w postrzeganiu świata społecznego. Analogiczną rolę odgrywa kulturowe modelowanie zachowań, wytwarzanie więzi społecznej i poczucia tożsamości w koncepcji systemu społecznego Talcotta Parsonsa.

Rolę ideologii rozumiemy dopiero wtedy, kiedy staramy się opisać, jak funkcjonuje całość społeczna złożona z gospodarki, państwa, $\mathrm{z}$ różnych form kultury duchowej, osadzona w jakimś lokalnym ekosystemie. Żeby jednostka mogła podejmować role przewidziane $w$ warunkach określonego podziału pracy i podziału bogactwa społecznego, warunki te w jej spontanicznym, myślowym obrazie świata społecznego, muszą zostać zarejestrowane, przeżyte, „rozpoznane”. I to rozpoznane w swoistej logice myślenia potocznego. Tak się dzieje, gdyż założenia co do konstrukcji świata społecznego w potocznym myśleniu są niewyartykułowane, nieświadome, tworzą strukturę myślową narzucaną ludziom poza ich wiedzą. Dla świadomości potocznej świat społeczny jest pozornie poznawalny i przejrzysty, co wspiera poczucie oczywistości. Nieprzejrzysty dla świadomości potocznej jest natomiast świat polityki. Należą do niego zjawiska władzy, mechanizm demokracji parlamentarnej, źródła bogactwa społecznego, gra geopolityczna mocarstw, podział pracy pomiędzy polityków, biurokrację i ekspertów. Jak stwierdza David Ost, „nieprzejrzystość władzy jest być może głównym atutem politycznym kapitalizmu, z jej powodu bowiem opozycja polityczna jest podzielona - każdy wskazuje innego wroga, którego obarcza odpowiedzialnością za wszelkie problemy" (Ost, 2007, s. 60). Dlatego pozaświadomościowy świat społeczny jednostki jest zapośredniczony przez ideologię; dlatego ludzie dzięki ideologii uświadamiają sobie swoje miejsce na świecie i w historii. Przeważa jednak w tym obrazie nie tyle stosunek ludzi do warunków ich egzystencji, ile sposób, w jaki przeżywają oni ów stosunek, co zakłada zarówno relację rzeczywistą, 
jak i „przeżywaną, wyobrażoną". To zatem jedność rzeczywistego i wyobrażonego stosunku ludzi do realnych warunków ich egzystencji społeczno-historycznej. Polega to na tym, że „relacja rzeczywista zostaje wpisana w wyobrażeniową, w relację, która raczej wyraża pewną wolę (konserwatywną, konformistyczną, reformistyczną lub rewolucyjną), czy wręcz nadzieję albo tęsknotę, niż opisuje rzeczywistość" (Althusser, 2009, s. 269, podkr. oryg.). Przy czym zróżnicowanie ideologicznych obrazów, właściwych różnym klasom, jest skutkiem sprzeczności obecnych w każdej praktyce społecznej (zwłaszcza gospodarczej). Oswaja te sprzeczności, gdyż ustala określony porządek dominacji i podporządkowania, korzystny dla klasy panującej ekonomicznie. Oswaja w ten sposób, że adaptuje wyobrażenia o legitymizacji panującego ładu społecznego, by przeżywany stosunek do świata mógł jej samej wydać się „realny”, słuszny, usprawiedliwiony.

W obecnie panującej ideologii liberalnej kreślącej ontologię współczesności omawiane salto mortale wygląda następująco. Głosi ona narrację nowoczesności, w której jednostka może jednocześnie doświadczać wolności, równości i być zarazem racjonalna. Dzieje się to za sprawą rynkowej wymiany i rynkowej logiki produkcji, w której każda jednostka może podejmować wybraną przez siebie dziedzinę przedsiębiorczości bądź zatrudnienia (wolność gospodarcza), może zawierać transakcje kupna-sprzedaży (także jako właściciel ergodynamis) bez dyskryminacji (równość umów, kontraktów). Na tej podstawie zgodnie $\mathrm{z}$ logiką produkcji każdy podmiot postępuje racjonalnie jako producent, konsument, gdyż maksymalizuje korzyści z posiadanych zasobów (zasada racjonalności homo oeconomicus). Obowiązuje tu prakseologiczna zasada - uzyskać największy efekt $\mathrm{z}$ posiadanych zasobów $\mathrm{w}$ warunkach konkurowania $\mathrm{z}$ innymi. Oni także są równi i wolni w swoich dążeniach do zaspokajania potrzeb. Wtedy pula wartości użytkowych wzrasta według Smithowskiego schematu: $\mathrm{T} \rightarrow \mathrm{P} \rightarrow \mathrm{T}$. Wymiana rynkowa posiadanych przez jednostki zasobów powiększa dobrobyt wszystkich: i książąt i kupców, słowem obywateli; gwarantuje im równość prawnopolityczną w sferze publicznej, czyli na rynku. To pole ideologicznie zagospodarowała socjotechnika równości szans, operująca skutecznie „przesądem równości": od pracownika fast foodu do miliardera. To jednak tylko płaszczyzna odniesienia prawdziwych relacji między uczestnikami praktyki ekonomicznej społeczeństwa.

Każdy obywatel to bądź kupiec, bądź książę, a także współcześnie: menedżer bądź robotnik, a może rentier lub emeryt, prekariusz lub bezdomny. Ale też Polak albo Syryjczyk, Afrykanin czy Azjata. Tak więc ludzie w rzeczywistych procesach gospodarowania nie są równi. Jedni mogą kontrolować warunki pracy innych (własność prywatna środków produkcji i wymiany), posiadają bowiem maszyny, budynki, zasoby kapitału pieniężnego. Mogą za nie nabywać niezbędne surowce i pracę innych, traktowaną jako towar nabywany na rynku. Rynek 
wówczas jest tylko mechanizmem koordynacji pracy, na którym produkty stają się towarami, tak samo jak przyroda i siła robocza pracowników. Są oni również wolni, ale od innych czynników produkcji. Żyjący z pracy własnych rąk i umysłów ma wolność wyboru pracodawcy, bo dysponuje swoją siłą roboczą jako towarem. To gwarantuje porządek prawny. Ostatecznie każde dobro i każda usługa może się stać towarem - zdrowie, edukacja, preferencje konsumenckie, las wilgotny, dorobek kulturowy narodów. Wówczas dominuje logika akumulacji kapitału, gromadzenia zysku netto, abstrakcyjnego bogactwa pomnażanego bez końca bez względu na koszty zewnętrzne dla spójności społecznej, globalnego ekosystemu, potrzeb rozwoju kulturowego. Pracownik może zmienić pracodawcę, ale nie klasę, do której należy. Ostatecznie reprodukuje tylko swoją siłę roboczą. Właściciel kapitału pieniężnego, produkcyjnego, handlowego może natomiast dodatkowo powiększać swoje zasoby mocy społecznej. Prowadzi ona ostatecznie do jednostronnej władzy kapitału, władzy korporacji nad zmuszonymi do sprzedaży swej ergodynamis klasami pracowniczymi, nad warunkami ich pracy i płacy, a także nad bezpośrednimi dysponentami instrumentarium państwa. $\mathrm{W}$ ten sposób wolność zmienia się w dominację, równość w wyzysk, a racjonalność gospodarki w destrukcję tkanki społecznej i równowagi biosfery. Trwałość ładu społecznego podtrzymują zatem funkcjonalne „niezbędniki” - przymus zdobywania środków konsumpcji przez posiadających tylko ergodynamis, i logika akumulacji kapitału („kapitaliści zarabiają tyle, ile wydają”). Nie można tutaj oderwać od siebie ekonomicznego i politycznoprawnego aspektu funkcjonowania całości społecznej. Możliwa jest tylko integralna analiza łącząca w spójny system kategorialny gospodarkę, państwo i demokrację, ideologię i kulturę. Analiza taka jest możliwa na gruncie ekonomii politycznej czy makrosocjologii.

Poznanie teoretyczne w naukach społecznych osadzone jest w ideologicznej perspektywie różnych klas społecznych. Kształtuje się ono jako narzędzie wyjaśniania struktury i dynamiki świata społecznego oraz zbiorowego losu i indywidualnych biografii biegnących w konkretnych wspólnotach Homo sapiens, a mianowicie - dla ekonomistów klasycznych i neoklasycznych podstawą ujęcia procesu gospodarowania jest schemat $\mathrm{T} \rightarrow \mathrm{P} \rightarrow \mathrm{T}$, więc wytwarzanie wartości użytkowych przez ludzi kalkulatorów w warunkach wolnej konkurencji i wolnego handlu. Efektywne rynki dzięki mechanizmowi cenowemu prowadzą do optymalnej alokacji zasobów, dlatego może powstać równowaga ogólna i rosnąć dobrobyt społeczny. Wszakże pod warunkiem że naturalnego procesu regulacji rynkowej nie wypacza państwo. O wartości dóbr decyduje subiektywnie oceniana przez konsumenta użyteczność. Jest to więc nauka praktyczna, użyteczna wartość dla posiadających w różnej postaci kapitał. Podpowiada im, jak osiągać możliwie duże zwroty z kapitału, a obecnie jak maksymalizować „wartość dla akcjonariusza" na drodze kapitalizacji giełdowej. Gdzieś ginie władza korpo- 
racji, będąca bezpośrednim skutkiem oligopolizacji gospodarki. Mimo wiązek rozmaitych praw własności nieobecne są stosunki ekonomicznie własnościowe, a wraz z nimi zanika podstawowy stosunek między kapitałem a pracą najemną. W konsekwencji nie liczy się to, że do wolnej konkurencji na starcie jedni stają z ogromnym majątkiem i dochodami, a drugich razi teraz „broń matematycznej zagłady" w postaci testów wykorzystujących przy angażu do pracy sztuczną inteligencję (szerzej: O’Neil, 2017). Praca to tylko „czynnik podaży”, zasób, w języku Karla Polanyiego - towar fikcyjny. W sumie więc rynek nie jest konstruowany historycznie i społecznie, nie zależy od instytucji społecznych, organizacji. Jest darem niebios dla przedsiębiorczej jednostki.

Nauka o polityce jako typ praktyki społecznej, jako forma świadomości społecznej i jako gatunek wiedzy ma również dostarczać dyrektyw, które umożliwiają przewidywanie następstw podejmowanych czynności, czyli decydujących o skuteczności działań ludzi w ich społecznym środowisku - czy to rządzących, czy rządzonych. By realizować te cele, badacz polityki wykracza poza horyzont partykularnych perspektyw poznawczych, ideologicznych obrazów życia społecznego. Musi ogarnąć społeczeństwo jako całość, by rekonstruować te sprzeczności i uwarunkowania, na które odpowiada (albo i nie) i które skrywa ideologia.

$\mathrm{Na}$ głębszym poziomie analizy badacz ustala teoretyczne przesłanki, czyli problematykę, w której skupia się sens podstawowy danej ideologii, jej problemy i wskazywane rozwiązania.

Nauki o polityce, podobnie jak pozostałe nauki społeczne, pozostają pod wpływem czynników „świadomościowych”, osadzonych w partykularnej kulturze. Pod względem treści nauki społeczne są mniej autonomiczne i suwerenne (Nowak, 1998, s. 36-42). Kształtowane są bowiem przez różne „obrazy świata”: systemy ideologiczne, systemy naukowo-filozoficzne oraz wyobrażenia o świecie, jakie wytwarza świadomość potoczna poszczególnych klas i stanów społecznych. Główną przyczyną tego stanu rzeczy jest brak związku między odkryciami nauk o człowieku i społeczeństwie (włączając w to także oddziaływanie dyskursów ideologicznych, religijnych czy świeckich) a technikami i technologiami produkcji, nowymi produktami itd. Tych dostarczają przecież nauki przyrodnicze i stosowane. W konsekwencji nauki społeczne nie mają wpływu na rozsądkową racjonalność ludzi w podstawowej, a więc gospodarczej, sferze życia społecznego. Bo tylko właściciel kapitału finansowego, handlowego czy produkcyjnego wie najlepiej, jaki rodzaj inwestycji zaowocuje największym zwrotem. Dochodzi tu do odseparowania racjonalności, która kieruje procesami gospodarowania, od racjonalności poznawczej w naukach społecznych (Karpiński, 1991, s. 264-269).

Racjonalność poznania humanistyki i w rezultacie powstające narracje mają charakter dialektyczny. $Z$ jednej strony reprezentują w ukrytej formie (ideologiczno-politycznej) partykularne interesy klas i stanów społecznych, z drugiej 
zaś dążą do prawomocności zapożyczonej z nauk ścisłych. Powstaje wówczas ogromna przestrzeń dyskursu publicznego, w której poszczególne paradygmaty naukowo-filozoficzne służą jako „tarcza i miecz” dla rozsądkowej racjonalności ludzi. Stają się funkcjonalne wobec interesów klas i wielkich grup społecznych, często nawet wbrew wyobrażeniom badaczy. Nic więc dziwnego, że politologia w czasach PRL-u obracała się w kręgu problemów funkcjonowania „demokracji” kierowanej przez przewodnią siłę. Obecni zaś politolodzy racjonalizują funkcjonowanie „demokracji reprezentacyjnej” i „społeczeństwa obywatelskiego". Jest im łatwiej, gdyż demokracja i prawa człowieka legitymizują kapitalizm, a zatem wszyscy oni mają swój niebagatelny udział w naturalizacji systemu. W tej transformacji pola badawczego przejawia się umiejętność ideologicznej mimikry.

\section{Politologia postpolityczna}

Wraz z marksizmem polscy politolodzy usunęli na dwie dekady z pola badawczego dynamikę i następstwa klasowego charakteru społeczeństwa rynkowego, a zatem społeczeństwa, w którym praca i przyroda są tylko zmiennymi w równaniach rentowności przedsiębiorców; społeczeństwa, w którym istnieją wyzysk, alienacja i dominacja. Okazało się, że twórczy był pluralizm paradygmatów badawczych, dopóki był sterylnym na inspiracje dorobkiem „najwnikliwszego krytyka społeczeństwa rynkowego", jakim bez wątpliwości był Karol Marks (zob. Walicki, 2013). Kiedy na świecie ukazują się książki o rewolucji energetycznej, podatku globalnym, konsekwencjach TTIP ${ }^{1}$ o życiu po neoliberalnym kapitalizmie - polska politologia wciąż iska „polityczność” w zakamarkach życia społecznego. Jest to swoisty samogwałt problemowy. Czyni to w nadziei, że znalezienie w końcu esencji mitycznej „polityczności” rozwiąże kryzys jej tożsamości, prestiżu akademickiego i malejącej społecznej doniosłości. Ponadto w obiegowej opinii politologów instytucja państwa jest neutralna w sensie takim, że stanowi instrumentarium kierowania życiem społecznym, a o dostępie do tego instrumentarium rozstrzygają wybory. Zgromadzona wiedza zaś ma mieć walory praktyczne dla społeczeństwa obywatelskiego. Przede wszystkim ma posłużyć do wzbogaconego prawami człowieka utrwalania demokracji jako wzorca systemu rządów na świecie. Jak ocenia Bronisław Łagowski (2014b), również polska politologia stała się powtórnie aparatem ideo-

TTIP (Transatlantic Trade and Investment Partnership) - Transatlantyckie Partnerstwo Handlowo-Inwestycyjne, porozumienie w sprawie handlu i inwestycji pomiędzy Unią Europejską a Stanami Zjednoczonymi. 
logicznym, zmieniła tylko patrona. Codziennym zadaniem stała się obsługa telemeledemokracji, rodzaju politologii stosowanej na gorąco, w studio telewizyjnym czy przed radiowym mikrofonem. Za neutralny ideologicznie uchodzi obecnie kanon liberalny. W tej narracji władzę sprawuje rynek, gdyż to on orzeka, co ile jest warte. Główni bohaterzy dramatu - korporacje, ich zarządy i właściciele - znikają $\mathrm{z}$ widzialnego pasma. $\mathrm{W}$ tej narracji liberalny kapitalizm stanowi naturalny porządek świata, odpowiada gatunkowi ludzkiemu, wyznacza wręcz „nieprzekraczalny horyzont ludzkości”. Polską odmianę tej dziecięcej choroby liberalizmu Rafał Woś nazwał celnie polonoliberaliozą (2014, s. 14). Zwłaszcza w opisie życia politycznego ignorowany jest fakt, że toczy się ono nadal $\mathrm{w}$ społeczeństwie klasowym. To tłumaczy rozliczne neutralizacje konfliktu przemysłowego, takie jak ograniczenia demokracji reprezentacyjnej, praw socjalnych czy tłumienie podziałów ideologicznych. Mówiąc wprost, wahadło aksjologiczne przechyliło się w drugą stronę. Obecnie w warstwie sterującej badaniami prawie całkowicie dominuje w głównym nurcie aksjologia bezalternatywnego liberalnego kapitalizmu w gorsecie reguł i organizacji międzynarodowych, skonstruowanych po II wojnie światowej przez USA. W tym ujęciu demokratycznemu kapitalizmowi może co najwyżej zagrażać populizm, narodowa prawica i globalny terroryzm. Jako datum przyjmowana jest we wszystkich naukach społecznych głównego nurtu aksjologia eklektycznego liberalizmu. Według Andrzeja Walickiego tworzy go rozpowszechniony w dyskursie naukowym, mediach i potocznym myśleniu zestaw następujących przekonań: (1) własność prywatna oraz wolny rynek (kapitalizm wolnorynkowy „nowej prawicy”) są święte; (2) retoryka uszczuplonych praw człowieka (cywilnych i politycznych, a nie społeczno-ekonomicznych); (3) wiara w uniwersalną zbawienność politycznej demokracji (sprzeciw wobec autokratyzmów) (Walicki, 2013, s. 338-339; Szahaj, 2014, s. 16).

W mainstreamowej strategii badawczej całkowicie ignoruje się systemowy kontekst mechanizmów polityki i funkcjonowania państwa, a mianowicie fakt, że scena polityczna wznosi się na filarach społeczeństwa kapitalistycznego. Imperatywem funkcjonalnym, któremu poddane jest to społeczeństwo, jest przymus akumulacji kapitału, samopomnażania się wartości, „abstrakcyjnej nadwyżki”. $\mathrm{Na}$ różne sposoby, w różnych formach instytucjonalnych i za pomocą różnych oddziaływań, w tym przymusu symbolicznego, swoją część zadania wypełnia w systemie społecznym państwo. Polityka w swojej istocie staje się formą krystalizowania wspólnej strategii klasy rządzącej, strategii kształtowania takiego ładu społecznego, w którym bogactwo pochodzi z kapitału, kontroli warunków pracy, dystrybucji i wymiany. Traktat TTIP negocjowany we własnym gronie, tylko z podziałem instytucjonalnych ról, jest kolejnym potwierdzeniem służebności polityków wobec biznesu. A zatem funkcje państwa, ostateczny rezultat polityki 
można poznawać tylko pośrednio, między innymi analizując strukturę podziału dochodów, zasięg mocy społecznej (władzy ekonomicznej, wpływu politycznego, upowszechnianej ideologii) posiadaczy różnych kapitałów.

Ten socjoekonomiczny eskapizm prowadzi do zerwania z najlepszymi tradycjami integralnej analizy polityki. Zamiast tego pole badawcze współczesnej politologii poszatkowane jest na osobne poletka, dobrze odgrodzone od sąsiednich specjalności (systemy polityczne, myśl polityczna, stosunki międzynarodowe, filozofia polityki itd.). Słabną przez to związki z dorobkiem ekonomii politycznej, makrosocjologii czy makrohistorii. Polscy politolodzy dali się ubiec ekonomistom (Tadeusz Kowalik, Grzegorz Kołodko, Jerzy Hausner, Jerzy Wilkin, Grzegorz Konat) i socjologom (Jacek Tittenbrun, Jan Sowa, Krzysztof Jasiecki, Jarosław Urbański) i prawnikowi Dawidowi Sześcile. Na szczęście pojawiły się prace przywracające do krwiobiegu polskiej politologii perspektywę analiz państwa jako stronniczego sternika bądź konstruktora ładu społecznego, w tym zwłaszcza ładu regulacyjnego (czy obecnie raczej deregulacyjnego) gospodarki (Kaczmarek, 2003; Laska, 2013; Pierzchalski, 2013; Klementewicz, 2015; Sześciło, 2015). Pionierem był w Polsce amerykański socjolog polityki David Ost (2007). Kryterium wyboru paradygmatu powinna być też jego przydatność w diagnozowaniu i kształtowaniu dalekosiężnej strategii rozwoju wspólnoty narodowej badacza, a nawet wspólnoty ogólnoludzkiej. Dla rozpoznania szans życiowych i stopnia upodmiotowienia ludzi ważna w dalszym ciągu jest analiza mocy społecznej różnych klas i stanów. Ta zaś w dalszym ciągu należy do tych, którzy mogą posługiwać się różnymi technologiami władzy w szerokim Foucaultowskim sensie.

\section{Etos politologa - przesłanka aksjologiczna działalności badawczej}

Zaangażowanie aksjologiczne badacza społecznego stało się przedmiotem debaty Michaela Burawoya z Piotrem Sztompką o socjologii publicznej. Podział zadań (i zleceń) przedstawiciela nauk społecznych rozciąga się tutaj między naturalizacją panującego ładu a krytyką społeczną. Swój ideologiczny stempel noszą bowiem szkoły badawcze, a także twórczość poszczególnych badaczy. Społeczeństwo obywatelskie, wolny rynek, demokracja przedstawicielska, klasa średnia - czy to kategorie teoretyczne, czy zamulające potoczne myślenie klisze ideologiczne? Kryzys hegemonii neoliberalizmu i niechlubna rola ekonomistów w triumfie kapitalizmu bez granic ekologicznych, społecznych, kulturowych - na nowo sformułowały pytanie o aksjologię zawodu. Uprawianie badań wolnych od wartościowań nie przeszkadza zwykle politycznemu powołaniu. Sam Weber jako nacjonalista niemiecki bez skrupułów skłaniał się do Realpolitik. Sama ideologia zawodu to za mało wobec wyzwań, 
które wciąż przynosi ludzkości system, w którym przybywa rolników bez ziemi, przedsiębiorstw bez pracowników i firm bez fabryk i robotników.

Funkcje dyscyplin społecznych sprowadzają się obecnie, podobnie jak kiedyś, do odpowiedzi na pytanie, jak służyć bogom tego świata? A mogą nimi być klasy, narody, ludzkość. Problem polega na tym, że w odróżnieniu od ideologa, kiedy badacz staje po stronie solidarności (dobra), musi też respektować obiektywizm. W przeciwnym wypadku jego pomoc byłaby zbędna, dekoracyjna. Mamy tu do czynienia $\mathrm{z}$ cienką granicą między rzetelnym myśleniem jako światłem na drodze działania a myśleniem jako bronią w hegemonicznych bojach klas. Jak pisał Alexandre Koyré, „[...] celem i funkcją myślenia, jak mówią, nie jest ujawnianie tego, co rzeczywiste, czyli tego, co jest, ale pomaganie nam w modyfikacji, transformacji tego, co jest, prowadząc nas ku czemuś, czego nie ma. Zatem, jak zauważono już dawno temu, częściej preferuje się mit niż wiedzę, częściej retorykę, która trafia do namiętności, niż dowód, który trafia do inteligencji” (za: Soin, 2017, s. 108-109).

Projekty reform zalecane ludziom żyjącym w danym społeczeństwie muszą być efektywne społecznie. A więc nie tylko muszą mobilizować wolę działania, ale przede wszystkim wskazywać środki działania. Przy czym takie środki, które pozwalają działającemu pokonać opór systemu instytucjonalnego, zarówno gospodarczego, jak i politycznego czy kulturowego. Wskazują konieczne, sprzyjające bądź niesprzyjające, warunki utrzymania, a często zmiany ram instytucjonalnych egzystencji społeczno-historycznej danej wspólnoty życia i pracy. W istocie praktyczna funkcja badacza sprowadza się do wskazania znaczenia, jakie określone zjawiska i procesy świata społecznego i przyrodniczego mają dla biologicznej i społecznej egzystencji ludzi, dla ich potrzeb materialnych i duchowych, dla ich wspólnotowej aktywności. Słowem chodzi o wartości, dobra służące zaspokojeniu zarówno ich potrzeb bytowych i kulturowych, jak i antywartości, wartości negatywnych, które utrudniają, wręcz niekiedy uniemożliwiają zaspokajanie danych potrzeb indywidualnych i zbiorowych. Wiedza będąca racjonalną podstawą dyrektyw praktycznych ma status poznawczy, jaki przysługuje wszelkim tezom o rzeczywistości. Może być zawodna, ale może być właściwa, może być uzasadniana teoretycznie bądź empirycznie. Wyróżnia ją jedynie zawartość treściowa, dotyczy bowiem stosunków i zależności wzajemnych między właściwościami świata przyrody i świata człowieka a cechami żyjących i działających w obu tych światach sprawczych podmiotów (szerzej: Kozyr-Kowalski, 1988, s. 673-679; zob. też: Opara, 2009, s. 54-63). Dodatkowym utrudnieniem jest zapośredniczony charakter głównych determinant zbiorowego losu ludzi. Głębokie przyczyny i uwarunkowania obserwowanych bezpośrednio zjawisk oddziałują za pośrednictwem innych zjawisk i procesów. Doniosłe są zwłaszcza te z nich, które znajdują się poza zasięgiem woli i wpływu jednostki, które wykraczają poza 
jej życiowe doświadczenia. Stwarza to okazje do zmistyfikowanych ujęć świata społecznego człowieka i jego miejsca w tym świecie. Na przykład niewidoczne bezpośrednio są przyczyny dysproporcji rozwojowych między regionami świata. Do ich ujęcia konieczna jest wiedza o rozwoju zależnym czy kapitalistycznej gospodarce-świecie, czyli odpowiednia wiedza teoretyczna, wiedza o społeczeństwie jako całości. Swoistymi ofiarami zmistyfikowanych wyobrażeń w świadomości potocznej stają się klasy, państwo jako twórca dobra wspólnego, naród jako wielka rodzina, dziejotwórcza rola jednostek i wydarzeń w zbiorowym losie narodu (Józef Piłsudski jako twórca niepodległości państwa). Pierwszy dylemat dotyczy tego, z czyimi potrzebami, interesami, wartościami powinien się utożsamiać politolog. Warunki realizacji określonych celów praktycznych wpisują się potem w katalog formułowanych pytań badawczych, a te ukierunkowują następnie praktykę badacza. Po wyborze problemu badawczego dalsze fazy badania muszą jednak przebiegać według reguł sztuki. Jest to warunek uzyskania walorów praktycznych. Każda nauka bowiem, przynajmniej potencjalnie, dostarcza wiedzy praktycznej, a więc informacji ułatwiających rozstrzyganie dylematów decyzyjnych. Politolog występuje tu jako quasi-badacz i quasi-ekspert (Młyńczyk, 2013). W grę mogą wchodzić różne identyfikacje. Czy problemy badawcze mają określać potrzeby trwania i rozwoju narodu jako wspólnoty etniczno-kulturowej? Czy raczej wielkie kolektywy, na które dzieli się każda wspólnota życia i pracy, a więc społeczeństwo mające określoną gospodarkę, kulturę duchową, trwające w danym lokalnym ekosystemie. Wspólnota współdziałających ludzi, dla podtrzymania i rozwoju materialnego i kulturalnego poziomu zaspokojenia potrzeb, stanowi w istocie „wspólnotę wspólnot”: wspólnot klasowych powstających w podziale pracy, własności, wspólnot religijnych, kulturowych, obyczajowych, ideologicznych. Każda z tych wspólnot ma z kolei swoje partykularne interesy. W gospodarce będą to posiadający różne kapitały, zarówno właściciel ergodynamis, jak i zatrudniający go czy kierujący nim menedżer. W tym przypadku politolog musi się zastanowić, czy wspierać młodszego brata politruka - ekonomistę bankowego, i jak on legitymizować kapitalizm? Czy raczej brać pod uwage potrzeby emancypacji i awansu społecznego klas pracowniczych? Zawsze są to jednak perspektywy racjonalności cząstkowej, partykularnej. Maksymalizuje ona co najwyżej potrzeby określonej klasy, wspólnot mniejszości czy większości etniczno-kulturowych.

Co zaś dotyczy potrzeb różnych mniejszości, celem praktycznym może być na przykład budowanie przestrzeni publicznej, w której spotykają się obywatele z różnymi tożsamościami kulturowymi. Obecnie chodzi głównie o potrzeby Europejczyków z korzeniami muzułmańskimi, jeśli dążą oni do integracji z kulturową większością, a zarazem pragną zachować istotne komponenty własnej tożsamości. Ich potrzeby to możliwość zachowania własnych obyczajów - stroju, modli- 
twy, żywności halal - w miejscu pracy, na ulicy. W demokratyczną przestrzeń publiczną wpisany jest konflikt, niezgoda, lęk. Ich rozwiązanie wymaga konsensusu i empatii, zrozumienia odmienności Innego i uszanowania jej (Göle, 2016, s. 278279). Uwzględnienie takiego partykularnego punktu widzenia wymaga od politologa przezwyciężenia europocentryzmu, i dużej odporności wobec utrwalonych stereotypów, rozpowszechnianych głównie przez media i polityków.

Badacz może jednak utożsamiać się z interesami i wartościami całej wspólnoty życia i pracy, czyli operować na poziomie całości społecznej. Przyjmuje wówczas punkt widzenia racjonalności ogólnospołecznej. Wtedy obranym kryterium jest panujący ład społeczny. Powstaje dylemat, czy ten ład racjonalizować ideologicznie, czy raczej szukać alternatywnych form organizacji społecznej, jeśli rodzi on stany dysfunkcjonalne. W pierwszym przypadku będziemy się rozpływać nad europejskim uniwersalizmem, z jego demokracją, prawami człowieka, wolnością, świętymi prawami własności (Walicki, 2013, s. 338-339; Nowicki, 2016, s. 32-37). Tu badający musi się licytować z dziennikarzami, którzy również upowszechniają ten wzorcowy model demokratycznego kapitalizmu. Przy okazji badacz bierze udział w propagandzie sukcesu III RP, opartego głównie na odzyskanej wolności i suwerenności. Jest bowiem faktem, że w Polsce: „kapitalizm prześlizgnął się dzięki emocjom narodowym nie mającym związku z gospodarką" (Łagowski, 2014a). Jeśli zaś stwierdzimy dysfunkcjonalność obecnego ładu instytucjonalnego, głównym zadaniem będzie wskazanie drogi pokonania pułapki średniego dochodu, zaproponowanie innej strategii narodowej dla dokończenia procesu modernizacji nie tylko półperyferyjnego kapitalizmu, ale również właściwej mu mentalności.

Dodatkowym argumentem na rzecz reprezentowania racjonalności ogólnospołecznej przez badacza jest system wynagradzania nauki. Ci naukowcy, którzy pracują na uczelniach publicznych, są finansowani przez polskiego podatnika. Podatki te płacą Polacy o najniższych dochodach płacowych. Świadczą o tym takie fakty, jak to, że większość osób płaci podatek liniowy w wysokości 19\%. Drugi i najwyższy próg podatkowy przekracza w Polsce 2,14\% podatników, a $60 \%$ zatrudnionych uzyskuje dochody poniżej średniej krajowej, czasami dwukrotnie. Wpływy z PIT-ów nie przekraczają $2 \%$ PKB. Jest to więc „kapitalizm bez socjalnego znieczulenia" (określenie Przemysława Wielgosza). Kolejny wskaźnik to stosunek funduszu płac do przychodów firm. W Polsce ten stosunek jest dwukrotnie niższy niż średnia w UE (i trzykrotnie niższy niż w Skandynawii) (Saratoga H.C. Benchmarking, 2012, s. 6; Bugaj, 2014). Polski system podatkowy ma więc charakter regresywny. Niskie dochody są relatywnie mocniej opodatkowane niż wysokie.

Możliwa jednak jest jeszcze inna aksjologia. To program rozwoju osobowości ludzkiej, nawiązujący do greckiego terminu paideia rozumianego jako ze- 
spół „Wzorców kulturowych” formułowanych w procesie edukacji, w systemie komunikacji społecznej. Kształtuje je całe dziedzictwo, jakie niosą mowa, pismo, druk (Mencwel, 2006, s. 394). To dziedzictwo ma ukształtować takie zasady współżycia społecznego, żeby znalazły odpowiednio eksponowane miejsce również potrzeby rozwojowe ludzi. Ważnym zadaniem jest tu znalezienie wspólnego mianownika, normatywnych podstaw współpracy i współdziałania ludzi różnych ras, tożsamości narodowych, obywateli dużych i małych państw, mieszkańców metropolii i głębokich prowincji. Byłby to proces kształtowania świadomości globalnej, obok narodowej i regionalnej. U jej podstaw leżą globalne dobra kolektywne. Uniwersum aksjologiczne tworzą wartości i dyrektywy wspólne wszystkim najważniejszym systemom religijnym i doktrynom etycznym (Lewandowski, 2007, s. 95; Singer, 2006, s. 164-206; Hobson, 2007, s. 149). Za najważniejszą w rozważanej perspektywie należy uznać złotą regułę etyki, zasadę wzajemności: Do ut des (łac. - daję, abyś i ty mi dał). Leży ona u podstaw wymiany społecznej, występuje u różnych gatunków, więc i u ludzi ma korzenie genetyczne. Kolejną cnotą naturalną jest umiarkowanie, aurea mediocritas (gr. - złoty środek). Namawiali do jej respektowania we własnym życiu między innymi Hezjod, Laozi, Konfucjusz, Budda, Sofokles, Arystoteles. W obliczu wyczerpywania się zasobów naturalnych może ona inspirować style życia nastawione na jego jakość. $Z$ wcześniej wymienionymi wiąże się spolegliwość, rozwaga, obowiązkowość, kompromisowość. Wszystkie one prowadzą do współżycia ludzi, wolnego od ciągłych konfliktów, napięć, wprowadzają przewidywalność reakcji, zwiększają zaufanie. Trudny dylemat powstaje w związku z harmonizowaniem równości i sprawiedliwości. Ta ostatnia żąda, by nierówności przy podziale dóbr były uzasadnione pracą i zdolnościami. Kolejną cnotą jest tolerancja, czyli zgoda na postawy inne niż nasze. Prowadzi do tolerancji uświadomienie sobie głębokich założeń i pewnej arbitralności czy partykularności własnej kultury. Potrzebna jest też otwartość intelektualna. Przeciwieństwem tolerancji jest fanatyzm, czyli kategoryczne przekonanie o bezwzględnej słuszności własnego postępowania i chęć sprawienia, by inni postępowali tak samo. W tej perspektywie zadaniem badacza jest ukazanie roli różnych dziedzin kultury duchowej, które wpływają na świadomość współczesnego człowieka, w tym zwłaszcza świadomości potocznej, regionalnej, narodowej, kosmopolitycznej. Świadomość ta rozwija się pod wpływem dyskursu ideologicznego. Dominują w nim motywy i hasła neoliberalizmu, ideologii demokracji i praw człowieka, ekologizmu czy fundamentalizmu religijnego. Pierwszy krok to odrzucenie i kompromitacja haikizmu, fundamentalizmu rynkowego, a więc odrzucenie absolutyzacji wolności, hiperindywidualizmu i darwinizmu społecznego. Dalsze zadania muszą zmierzać do przezwyciężenia statofobii, w tym zwłaszcza niechęci do progresji podatkowej. 
Drogowskazem dla badacza jest racjonalność poznawcza po przejściach, w dobie kryzysu realizmu. Na cenzurowanym znalazło się oświeceniowe mitologizowanie rozumu jako samowładnej instancji, ufundowanej na apriorycznych strukturach poznawczych (jak np. racjonalizm krytyczny Karla Poppera). Prawda, jako idea regulatywna nauki, musi być osadzona w kontekście społecznym, historycznym i kulturowym. Dopiero on pozwala objaśnić, dlaczego mamy w życiu społecznym roszczenia prawdziwościowe i domagamy się ich respektowania, zwłaszcza $w$ nauce. To on nadaje prawdzie charakter przygodny, a nie ponadhistoryczny i uniwersalny, gdyż prawda ma: „tyle postaci, ile odmian i historycznych form mają praktyki wspólnotowe, w których występuje" (Tuchańska, 2012, s. 33). Tak rozumiana prawda może chronić społeczeństwo przed ostrzałem ideologicznym mediów, przed pułapkami potocznego myślenia, może dostarczać prewidystycznych przesłanek programom działania.

\section{W stronę politologii krytycznej}

Dla oceny społecznych funkcji humanistyki istotne są pytania: Kto i w jakim celu korzysta $\mathrm{z}$ wiedzy gromadzonej przez akademię? Czy ma ona legitymizować istniejący ład społeczny, czy raczej szukać przyczyn jego zawodności? To drugie zadanie jest nie tylko trudniejsze, ale ma w sobie zarodki większej korzyści społecznej. Refleksja krytyczna jest bowiem zorientowana na zmienianie świata, w którym znajduje się co prawda kilkanaście rajów, ale to raje podatkowe dla kilkudziesięciu tysięcy miliarderów i milionerów. Zadania badacza krytycznego ostatecznie sprowadzają się do próby aktywnego kształtowania opinii publicznej za sprawą publikacji i udziału w praktykach dyskursywnych. To zadanie stało się ważniejsze $\mathrm{w}$ masowym zmediatyzowanym społeczeństwie, w którym fakty zastępują opinie, swobodne interpretacje. „Zasada ogólna ponowoczesnej samoświadomości nakazuje bowiem nie tylko zdeprecjonować rzekome fakty na rzecz ich arbitralnych interpretacji, ale również uwiarygodnić pożądaną interpretację j a k o rzeczywistość przez zabiegi maskujące jej arbitralność" (Soin, 2017, s. 31, podkr. oryg.). Przy czym krytyka społeczna nie musi naruszać obiektywizmu badawczego. Prowadzi ona bowiem do ujawnienia aksjologicznych podstaw pozornie autonomicznych działań jednostki, jak również praktyk społecznych ową autonomię organizujących. Będą to przede wszystkim dyskurs władzy, stosunki dominacji i wyzysku, przemoc symboliczna, wykluczenie. Dlatego tak ważna w krytyce społecznej jest perspektywa emancypacji klas podporządkowanych. Według Theodora Adorna „żadne poznanie nastawione na niedostępną bezpośrednio istotę społeczeństwa nie może 
być prawdziwe, o ile nie pragnie go zmienić, a więc o ile nie jest wartościujace" (za: Mokrzycki, 1984, s. 42, podkr. oryg.).

\section{$\star \star \star$}

Żeby całościowo (holistycznie) opisać proces funkcjonowania współczesnego społeczeństwa, trzeba połączyć cztery względnie odrębne aspekty:

- aspekt przyrodniczy (energia, surowce, ziemia, ekologiczne granice biosfery Ziemi - oikumene [gr. - zamieszkana ziemia]);

- aspekt techniki (myśl ludzka i narzędzia pracy);

- aspekt stosunków własnościowych, czyli władzy nad warunkami pracy, ich kontroli;- aspekt ideologicznego odzwierciedlania sprzeczności i tendencji rozwoju kapitalizmu bez granic.

Tworzą one rozbudowany system instytucjonalny. Te aspekty procesu gospodarowania stanowią przesłanki analizy procesu podziału wytworzonego bogactwa i społecznych konsekwencji tego podziału. Analiza przebiega według schematu: zasady podziału nadwyżki związane z prywatną własnością środków produkcji i wymiany oraz siły roboczej $\rightarrow$ konflikt przemysłowy $\rightarrow$ interesy i ruchy pracownicze oraz społeczno-polityczne.

Holistyczna analiza ujawnia stałe tendencje rozwojowe funkcjonowania społeczeństwa poddanego logice akumulacji kapitału:

1. Proces koncentracji produkcji i władzy ekonomicznej korporacji (oligopole, wielkie globalne korporacje). Z badań sieci powiązań własnościowych i przepływów finansowych między grupami kapitału finansowo-przemysłowego wynika, że 737 takich podmiotów kontroluje $80 \%$ pozostałych korporacji. Co więcej, trzon złożony z 147 grup finansowych (75\%) kontroluje 40\% systemu korporacyjnego (Dowbor, 2017, s. 145-150; Glattfelder, b.d.). Równolegle coraz węższa grupa posiadaczy akcji jest właścicielami majątku korporacji. $\mathrm{Na}$ przykład w USA tylko pięć osób jest właścicielami około 1/4 majątku, należącego formalnie do 500 największych amerykańskich korporacji (Lazonick, 2013, s. 883 , fig. 5).

2. Proces finansyzacji gospodarki. Odpowiada on za gargantuiczny rozrost sektora finansowego, dewaloryzację sektora przemysłowego, spadek stopy inwestycji i płac realnych, a w konsekwencji dysproporcjonalny podział bogactwa społecznego. Coraz wyższą barierę popytu tłumaczy dodatkowo zaburzony okrężny ruch dochodów. Zaburzają go stojące w miejscu płace realne, okrojone budżety państw, nieskuteczne „popychanie sznurka” przez banki centralne (ilościowe luzowanie pieniądza), brak przełomowych inwestycji. Wszystkie te „efekty zewnętrzne” zachłannej pogoni za rentą nie tworzą efektywnego popytu, który mógłby poruszyć maszynerię zysku. 
3. Pogłębianie się „gospodarki niewinnego oszustwa”, jak mit „władzy rynku” określił John Kenneth Galbraith (2005, s. 23). Rynek nie istnieje w próżni społecznej, kierują nim największe oligopole. Skrzętnie skrywana jest władza korporacji (reżimy międzynarodowe, rola jednostronnych agencji wielostronnych odgrywających rolę „odźwiernych” korporacji, takich jak MFW, WTO czy BŚ), a także usłużni politycy, w tym szczególnie obecna Komisja Europejska.

W rezultacie tych procesów kapitalistyczną gospodarkę spętał syndrom stagnacji (Klementewicz, 2015). Syndrom ów uchwycił system mocno, z wielu stron naraz. To:

1. Gospodarka (władza korporacji, oligopolizacja i finansyzacja akumulacji - offshoring);

2. Państwo (wygłodzony system podatkowy, hołdujący ordopolityce, neoliberalny Lewiatan, ubezwłasnowolniony przez „inwestorów” i „rynki finansowe" za sprawą mechanizmu długu publicznego);

3. System władzy z niewydolnym mechanizmem demokracji reprezentacyjnej. Służy on głównie, wraz z prawami człowieka, do legitymizacji sytemu gospodarczego. W rezultacie kapitalizm jest coraz mniej demokratyczny. Zdaniem Wolfganga Streecka zamiast kategorii przypisywanych demokracji liberalnej należy w państwie na kroplówce korporacji używać nowych, precyzyjniejszych kategorii. Czyli: zamiast woli obywateli - życzenia inwestorów; zamiast wyborców - wierzyciele; prawa obywatelskie należy zastąpić umowami, a opinię publiczną - stopami procentowymi (Streeck, 2014, s. 99-105). Dotychczasowy bowiem lud, Staatsvolk, zastąpił Marktvolk - ,instytucjonalni inwestorzy” w neoliberalnej grypserze, czyli finansjera, znani z imienia i nazwiska prezesi, członkowie zarządów, wielcy menedżerowie globalnych banków, funduszy ubezpieczeniowych, funduszy powierniczych, udziałowcy i właściciele ogromnych pakietów akcji, kapitału finansowego. Jak pisze Ladislau Dowbor, „[d]ziś centralnym wyzwaniem jest skonstruowanie demokratycznych procesów kontroli i alokacji zasobów" (2016, s. 39). Zanim to nastąpi, pojawi się, według określenia Streecka, postkapitalistyczne interregnum (2016, s. 13). Kapitalizm w centrum utraci makrosystemową sterowność, a na poziomie mikro będzie dominować indywidualna strategia „Ratuj się kto może!”;

4. Nauki społeczne. Ze środowiska naukowego rekrutuje się „klasa sług”, których misją jest naturalizowanie systemu. Jak pisze Jan Kurowicki:

Prawda i inne aksjologiczne cymelia, związane z etosem intelektualisty i uczonego, jeśli okazują się w tej służbie użyteczne, zostaną użyte tylko w myśl zasady: „Po co kłamać, skoro prawda się bardziej opłaca”. Jeśli wszakże ta prawda mogłaby jej zaszkodzić, odbiegać od norm poprawności politycznej, stworzy ona mniej lub bardziej ponętne intelektualnie sposoby obniżenia jej rangi lub całkowitego zdezawuowania (Kurowicki, 2013, s. 150). 
To zadanie wypełnił postmodernizm, który podważył skutecznie obiektywizm badawczy, dorzeczność. Nauki krytyczne natomiast nie łudzą odbiorców, że ultranowoczesne techniki badawcze zapewniają neutralność ideologiczną. Kontynuują one oświeceniową postawę krytyczno-sceptyczną. Dlatego, zdaniem Streecka, potrzebny jest nowy projekt nauki społecznej. Politolodzy wspólnie z socjologami i heterodoksyjnymi ekonomistami powinni stworzyć nową ekonomię społeczno-polityczną, podporządkowaną nie maksymalizacji użyteczności neoklasycznej ekonomii, lecz harmonizacji celów społecznych (Streeck, 2016, s. 251);

5. Świadomość potoczna. To skuteczny plaster na rany dla prekariuszy, samozatrudnionych, pracujących w strefach specjalnych, wymachujących szturmówkami podczas patriotycznych wzmożeń. To domena racjonalności rozsądkowej, zwłaszcza klas pracowniczych. Ten sposób legitymizacji ładu społecznego różni się od umowy społecznej, tak chętnie używanego przez myśl liberalną wytrycha.

Dziś politolog musi dać odpowiedź na pytanie, w jakim modelu kapitalizmu mogą znaleźć rozwiązanie globalne problemy cywilizacji techniczno-naukowej w obecnej postaci neoliberalnego kapitalizmu. Wobec długotrwałego kryzysu strukturalnego (owo swoiste interregnum), w jakim znalazł się kapitalizm, bez granic pozostaje debata nad jego kolejną rekonfiguracją. Chodzi o taką organizację ogólnoludzkiej wspólnoty życia i pracy, która pozwoli zachować parametry zrównoważonego rozwoju, dobrobytu bez wzrostu, a zarazem umożliwi usunięcie dysproporcji rozwojowych między regionami świata. W nowej cywilizacji trwałego rozwoju skorygowane mechanizmy zglobalizowanego kapitalizmu muszą łączyć efektywność gospodarowania zasobami przyrody z bezpieczeństwem żywnościowym i socjalnym wszystkich mieszkańców Ziemi. Pozwalają na to moce produkcyjne i bogata baza naukowo-badawcza cywilizacji. Pułapce Meadowsa, czyli nieprzekraczalnym parametrom trwania biosfery, odpowiada sugerowana $\mathrm{w}$ wielu publikacjach rewolucja (transformacja) energetyczna (Jackson, 2015; Popkiewicz, 2015; Fücks, 2016).

Głównym warunkiem tej ewolucji będzie odzyskanie kontroli nad państwem. Gdyż dopiero państwa poddane demos mogą wspólnie kształtować nowe reguły funkcjonowania korporacji w światowej przestrzeni gospodarczej. Odzyskanie państwa będzie wymagało uzupełnienia demokracji reprezentacyjnej. Uzupełnią ją różne formy demokracji partycypacyjnej, współrządzenia (koprodukcji), w tym także pracowniczej. Nacisk ulicy, furor populi, w postaci ruchów społecznych - populistycznych, ruchów radykalnej i narodowej prawicy - to konieczny impuls zmian. Wzmożonych narodowo również wypycha na ulicę niepewność egzystencji, biedapraca i biedapłaca w neoliberalnym kapitalizmie.

Kryzys strukturalny systemu to magiczny czas, kiedy utopie stają się programami reform, a one prowadzą do stopniowego uspołeczniania gospodarki funkcjonującej w reżimie logiki zysku zamiast etyki trwałego rozwoju. 


\section{Literatura}

Althusser, L. (2009). W imię Marksa, przeł. M. Herer. Warszawa: Wydawnictwo Krytyki Politycznej.

Blok, Z. (2013). „Drogi poszukiwania tożsamości nauki o polityce”. Przegląd Politycz$n y, 4$.

Bugaj, R. (2014). „ «Wyższe podatki dla bogatych są konieczne». Z Ryszardem Bugajem rozmawia P. Skwirowski. Gazeta Wyborcza, 10-11.05.2014.

Czapnik, S. (2014). Władza, media i pieniądze. Amerykańska ekonomia polityczna komunikowania. Opole: Wydawnictwo Uniwersytetu Opolskiego.

Dowbor, L. (2016). „Przechwytywanie władzy przez system korporacyjny”. Le Monde diplomatique - edycja polska, 9 (127).

Dowbor, L. (2017). Co to za gra? Nowe podejścia do ekonomii. Warszawa: Instytut Wydawniczy Książka i Prasa.

Fücks, R. (2016). Zielona rewolucja, przeł. Ś.F. Nowicki. Warszawa: Instytut Wydawniczy Książka i Prasa.

Galbraith, J.K. (2005). Gospodarka niewinnego oszustwa. Prawda naszych czasów, przeł. G. Łuczkiewicz. Warszawa: MT Biznes.

Glattfelder, J.B. (b.d.). The Network of Global Corporate Control - Revised, www.bit.ly/ pWsIEs (dostęp: 21.11.2016).

Göle, N. (2016). Muzułmanie w Europie. Dzisiejsze kontrowersje wokół islamu, przeł. M. Ochab. Kraków: Karakter.

Hobson, J.K. (2007). „Deconstructing the Etnocentric Clash of Civilisations: De-Westernising the West by Acknowledging the Dialog of Civilisations". W: M. Hall, Ph.T. Jackson. Civilisations and International Relations Theory. New York-Basingstoke: Palgrave Macmillan.

Ingham, G. (2011). Kapitalizm, przeł. S. Królak, K. Sosnowska. Warszawa: Sic!

Jackson, T. (2015). Dobrobyt bez wzrostu. Ekonomia dla planety o ograniczonych możliwościach, przeł. M. Polakowski. Toruń: Wydawnictwo Naukowe Uniwersytetu Mikołaja Kopernika.

Kaczmarek, B. (2003). „Polityka jako proces organizacji życia społecznego”. W: B. Kaczmarek (red.). Metafory polityki, t. 2. Warszawa: Elipsa.

Karpiński, R. (1991). Świadomość potoczna jako kategoria świadomości społecznej. Próba eksplikacji krytycznej. Katowice: Akademia Nauk Społecznych.

Karwat, M. (2012). O karykaturze polityki. Warszawa: Wydawnictwo Literackie Muza.

Klementewicz, T. (2015). Stawka większa niż rynek. U źródeł stagnacji kapitalizmu bez granic. Warszawa: Instytut Wydawniczy Książka i Prasa.

Kozyr-Kowalski, S. (1998). Struktura gospodarcza i formacja społeczeństwa. Warszawa: Książka i Wiedza. 
Krauz-Mozer, B., Ścigaj, P. (2013). „Sklep z podróbkami? Podejścia badawcze i metodologie w nauce o polityce”. W: B. Krauz-Mozer, P. Ścigaj (red.). Podejścia badawcze i metodologie w nauce o polityce. Kraków: Księgarnia Akademicka.

Kurowicki, J. (2013). Figury i maski w praktykach ideologicznych. Warszawa: Instytut Wydawniczy Książka i Prasa.

Laska, A (red). (2013). Marksowskie inspiracje w badaniach polityki. Warszawa: Difin.

Lazonick, W. (2013). „The Financialization of the U.S. Corporation: What Has Been Lost, and How It Can Be Regained". Seattle University School of Law, 36 (2), s. 857-909.

Lewandowski, E. (2007). „Konfrontacje cywilizacyjne”, Dziś, 1.

Łagowski, B. (2014a). „Wielka księga”. Przegląd, 19-25 maja 2014.

Łagowski, B. (2014b). „Strefa partyjna”. Przegląd, 1-7 grudnia 2014.

Mencwel, A. (2006). Wyobraźnia antropologiczna. Próby i studia. Warszawa: Wydawnictwo Uniwersytetu Warszawskiego.

Młyńczyk, Ł. (2013). „Politolog w «sporze» z metodą. Quasi-badacz a quasi-ekspert”. Atheneum. Polskie Studia Politologiczne, 39.

Mokrzycki, E. (1984). Kryzys i schizma. Antyscjentystyczne tendencje w socjologii wspótczesnej, t. 2. Warszawa: Państwowy Instytut Wydawniczy.

Nowak, L. (1998). „O ukrytej jedności nauk społecznych i nauk przyrodniczych”. Na$u k a, 1$.

Nowicki, F. (2016). „Idea demokracji a rzeczywistość. Tezy o ideologii europejskiego uniwersalizmu". Studia Politologiczne, 41, s. 62-67.

O’Neil, C. (2017). Broń matematycznej zagłady. Jak algorytmy zwiększają nierówności i zagrażaja demokracji, przeł. M.Z. Zieliński. Warszawa: Wydawnictwo Naukowe PWN.

Ollman, B. (2000). „What is Political Science? What Should it Be?”. New Political Science, $22(4)$.

Opara, S. (2009). Tyrania złudzeń. Studia z filozofii polityki. Warszawa: Warszawskie Wydawnictwo Literackie Muza.

Ost, D. (2007). Klęska „Solidarności”. Gniew i polityka w postkomunistycznej Europie, przeł. H. Jankowska. Warszawa: Wydawnictwo Literackie Muza.

Pierzchalski, F. (2013). Morfogeneza przywództwa politycznego. Pomiędzy struktura a podmiotowościa sprawcza. Bydgoszcz: Wydawnictwo Uniwersytetu Kazimierza Wielkiego.

Popkiewicz, M. (2015). Rewolucja energetyczna. Ale po co? Katowice: Wydawnictwo Sonia Draga.

Saratoga HC Benchmarking 2012. Wyniki analizy. (2012). Warszawa: PricewaterhouseCoopers.

Singer, P. (2006). Jeden świat. Etyka globalizacji, przeł. C. Cieśliński. Warszawa: Książka i Wiedza.

Soin, M. (2017). Kryzys filozofii i zadanie krytycznego myślenia. Warszawa: Wydawnictwo Instytutu Filozofii i Socjologii PAN. 
Streeck, W. (2014). Buying Time: The Delayed Crisis of Democratic Capitalism. London: Verso.

Streeck, W. (2016). How Will Capitalism End? London-New York: Verso.

Szahaj, A. (2014). Kapitalizm drobnego druku. Warszawa: Instytut Wydawniczy Książka i Prasa.

Szahaj, A. (2015). Inny kapitalizm jest możliwy. Warszawa: Instytut Wydawniczy Książka i Prasa.

Sześciło, D. (2015). Samoobsługowe państwo dobrobytu. Czy obywatelska koprodukcja uratuje ustugi publiczne. Warszawa: Wydawnictwo Naukowe Scholar.

Tuchańska, B. (2012). Dlaczego prawda? Prawda jako wartość w sztuce, nauce i codzienności. Warszawa: Poltext.

Walicki, A. (2013). Od projektu komunistycznego do neoliberalnej utopii. Kraków: Universitas.

Woś, R. (2014). Dziecięca choroba liberalizmu. Warszawa: Studio Emka.

\section{Streszczenie}

W artykule wskazuje się na pozorną neutralność aksjologiczną i ideologiczną współczesnej polskiej politologii. Poznanie teoretyczne w naukach społecznych osadzone jest w ideologicznej perspektywie różnych klas społecznych. Nauki o polityce, podobnie jak pozostałe nauki społeczne, pozostają zatem pod wpływem czynników „świadomościowych”, osadzonych w partykularnej, europejskiej kulturze. Pod względem treści nauki społeczne są mniej autonomiczne i suwerenne. Także nauka o polityce legitymizuje ład instytucjonalny, który utrwala władzę ponadnarodowych korporacji nad państwami, pracą, naturą i umysłami. Dlatego krytyczny politolog powinien się kierować racjonalnością ogólnospołeczną i planetarną w swoich analizach problemów i tendencji rozwojowych, które rodzi neoliberalna konfiguracja kapitalizmu bez granic.

Słowa kluczowe: ideologia, poznanie teoretyczne, konflikt redystrybucyjny, ideologiczna funkcja nauki o polityce, politologia krytyczna, ogólnospołeczna i planetarna racjonalność 